\title{
Nyanyian Panjang Bujang Si Undang as oral tradition in Melayu Ethnic; an alternative approach for mental revolution
}

\author{
Erni Erni ${ }^{1}$, Hasanuddin WS ${ }^{2}$, Harris Effendi Thahar ${ }^{3}$, Yasnur Asri ${ }^{4}$ \\ ${ }^{1}$ Universitas Islam Riau, Pekanbaru - Indonesia (ernirusli65@gmail.com) \\ ${ }^{234}$ Universitas Negeri Padang, Padang - Indonesia
}

\begin{abstract}
This study aimeds to describe the form of mental revolution in NyanyianPanjangBujang Si Undang which is viewed from six aspects tunjuk ajar, namely faith to God, honesty, intelligence, integrity, caring, and nationality. This study was a qualitative research using descriptive method. The data in this study were the character of educational value from the narrator, characters' utterance and characters' act which werecollected through format of data inventory. The data were analyzed based on Miles dan Hubeman's models through three steps; data reduction, data display and conclusion. There are six forms mental revolution on the characters of educational value in NyanyianPanjangBujang Si Undangnamely faith to God, honesty, intelligence, integrity, caring, and nationality. Therefore, NyanyianPanjangBujang Si Undang as oral tradition inheritance can be used as the alternative in supporting the education from local wisdom of Melayu society to solve the problems of morality and ethic.
\end{abstract}

Keywords: oral tradition, mental revolution, melayu ethnic, nyanyian panjang bujang si undang

\section{Introduction}

There are some reasons why this research needs to be done. First, one of the government's program, president Jokowi, is a mental revolution. This program needs to be responded wisely since the condition of Indonesian's society is in the level of significant chaotic that affects on the faded of society's self-actualization. Other fact that is important to support mental revolution is nowadays almost all Indonesian society (including the young people) always find the news from mass media about chaos and dispute among ethnic group and religion. This news makes us apprehensive and disappointed. Even it is also along with the anarchy that become the "trend" in all part of life, politic, economic, social and religion in all over the world including Indonesia.

Second, in the law UndangUndangDasar (UUD) 45 chapter XIII article 32 subsection 1 stated that negara memajukan kebudayaan nasional di tengah peradaban dunia dengan menjaminkebebasan masyarakat dalam memelihara dan mengembangkan nilai-nilai budayanya (the country modernize and protect the national culture in the middle of world civilization by guarantee the citizen's freedom in protecting and developing their values of culture). In subsection 2, it is stated that negara 
menghormati dan memelihara bahasa daerah sebagaikekayaan budaya nasional. These statements mean that country give important media for cultures including native language that is the part of local culture.

Third, one of the base philosophy in the development of Curriculum 2013 roots on the local and national culture. It means that curriculum must give the chance to the students to learn from local and national culture about essential value of life. Curriculum also give the chance to them to participate in developing local and national culture's value become the value that can be applied in daily life and developed for the next generation. Based on this base philosophy, it can be assumed that NP oral tradition of the people from Petalangan Kabupaten Pelalawan Provinsi Riau is a part of potential local and national culture that has the values that can be used by the students. Sugono (2004:vi) mentions that the values in old literature like society's prose that contains the information about past life, needs to be presented nowadays in all aspect of life including in culture, language and literature education. It is important since the literature contains of the knowledge about past life that has essential role in guiding the present and future's life. According to HasanuddinWS (2009:27), literature from past time take a part as one of the moral education today especially about the moral character value that is positively acted.

Fourth, the study about "Tunjuk Ajar Melayu Riau inOral Tradition of NP people Petalangan Kabupaten Pelalawan Propinsi Riau" needs to be done, because it is useful for the reflection of the way of thought, knowledge and hope. It is also important as the documentation, inventories and media of culture value exploration of Tunjuk Ajar Melayu and the special function for the society. Oral tradition can be said as the manifestation of the culture is the region that shows civilization of the society in one period. Some efforts isneeded in order to document this oral tradition to prevent the possibility of extinction.

Based on the reasons above, the exploration of Tunjuk Ajar Melayu values in Oral Tradition of NP people Petalangan Kabupaten Pelalawan Propinsi Riau needs to be researched to make the meanings can be applied in the society. Moreover, it shows that the society's prose is not only contains of legend that can be read by the children but also has the appreciated culture values.

\section{Method}

Researcher used the descriptive qualitative methode, the text of nyanyi panjang in Bujang si Undang (next it is shorten into BPBSU) has been chosen as the object of research. There search about moral values of Tunjuk Ajar Melayu in the lyrics of nyanyian panjang by Petalangan people, Pelalawan district, Riau's province, is a content analysis study. The activity of this research is to analyze the contents of literature, bacause the literature is a product of communication between the author and the environment (Hasanuddin WS, 2003:40). This object explained by using the relation between the information togather the tunjuk ajar moral values.The processof describing and explaining is continued by interpretation. The content analysis technique used to analyze sistematically the data or the content sorthe messagesin thet ext. Content analysis encompassing related matters to language aspects such as syntax, referential, andpropositional. Syntax aspect isincludingword, phrases, clauses,or sentences in the story text which related to reference or matters referredand coherence between sentence in the story text or propositional (Krippendorff,dalamMoleong,1999:163).

\section{Result and Discussion}

Some relevant researches with this research are the research done by Yonhee Kang in 2005 about oral tradition in Riau. Yoonhee Kang (2005) had done a research of oral tradition in Riau entitled Untaian Kata Leluhur. Yoonhee Kang did an analysis toward the ritual of medical treatment named belian, song of collecting honey named menumbai, and magic spells pengasih and pemani. This research was his dissertation in Yale University in United States. 
Moreover, the research about oral tradition was previously done by Nigel Phillips (1981) which is about oral tradition in Lima Puluh Kota regency in West Sumatera Province entitled "Si Jobang: Sung Narrative Poetry of West Sumatra". This research was his dissertation in London University. Research related with local value was done by Edwar Djamaris et.al. in 1994 entitled Sastra Daerah di Sumatera: Analisis Tema, Amanat dan Nilai Budaya. In this research, seven folklores from seven provinces in Sumatera were analyzed using objective approach, short stories in Riau are ten in amount. Based on the data description, there are some moral values such as warmness, some tactics, respect to the king, justice, patient and endurance, low profile, honesty, well-mannered and responsibility.

There are five tunjukajar NPBSU that can be used as the reference to see ideal characters of people from Petalangan, (1) faith and belief to God, (2) honesty, (3) intelligence, (4) integrity and (5) care. The explanation of each, can be seen as follow.

\section{Tunjuk Ajar of Faith and Belief to God in NPBSU}

The character of faith and belief to God is one character that involved thought, utterance, and act of someone in his/ her religion. Findings shows that the value of character education in NPBSU focus on the faith and belief to God is described from the obedient and trusteeship to parents. All of culture values and social norms of people in MelayuPetalangan must refers to Islam. Culture values that are not suitable with Islam need to be direct well or push aside. This reference makes Islam cannot be separated from culture, tradition and social norms of people in MelayuPetalangan.

The closeness of Melayu people with Islam can be seen from Tunjuk Ajar Melayu that has values of Islam education(Effendy, 2004:33-46). BujangsiUndang shows his respect to his mother by asking his mother to eat sirih and kiss her hand. This procession is the way to ask permission before going shoreline. Based on this tunjuk ajar, it can be understood that children from MelayuPetalangan respect the parents especially mother.

Moreover, tunjuk ajarof faith and belief to God in NPBSU can be seen from the obedient of character to the leader. In MelayuPetalangan, obedient to "older people" or leader is an essential thing. Leader needs to be respected and obeyed as long as he is responsible (Effendy, 2004:51-62). It can be seen from the respect of BujangsiUndang to DatuknanEmpat.

The respect of Bujang is shown from the words and utterance of Bujang when he arrive shoreline and wants to know where the DondangPanjang is. His utterance and words to DatuknanEmpat represented the citizen that obey and respect his leader. In MelayuPetalangan, a leader is the role model that should be obeyed and respected. BujangsiUndang still respect the leader although he just want to get the justice from the leader.

Moreover, the character of trusteeship is also shown by BujangsiUndang when his mother give him advice, he is not angry. It is suitable with the words "Orang amanah membawa tuah" (trusteeship people bring good luck), orang amanah hidup bermewah (trusteeship people live in prosperity) and "Orang amanah dikasihi Allah." (trusteeship people loved by Allah)(Effendy, 2004:385-386).

Tunjuk ajarNPBSU teach citizen to be well judged with others. It makes the relationship with other ethnic, race and religion groups run well. Moreover, there are some things that relate with tunjuk ajar to be shy. In tunjuk ajar, shyness is the reflection of moral. It is implied in antagonist character of Datuk nan Empat. Datuk nan Empat feel embarrass of what he done in Bujang si Undang heirloom. It is hard for him to stare at Bujang's eyes. He feel embarrassed because he lost Dondang Panjang, the heirloom from Bujang's family. Beside, he is also murder Bujang si Undang's brother named Kubin. Furthermore, Melayu Petalangan people must not shy in getting knowledge, confessing his own mistake, being honest, getting advice and etc.(Effendy, 2004:211-212). 
Another interesting thing that is found in NPBSU is the tunjuk ajar about self concern. Self-concern in MelayuPatalangan's reference is the awareness of self toward life, purpose of life and rights and responsibility as citizen and the servant of God. Self-concern people able to place himself in the society. He is also able to have good manner. In NPBSU, it is found that there is a religious advice that remind Bujang to always remember his origin and not soundly asleep with the success shoreline(Effendy, 2004:343-344).

The last thing that can be discussed about faith and belief to God in tunjuk ajar in NPBSU is the character of forgiveness and open hearted. Adat saying "siapa taat memeluk agama islam, dendam kesumat ia haramkan" (who obey Islam, forbid the revenge) or "siapa setia memegang adat, dendam kesumat itu pantangkan" (who faithful the tradition, forbid the revenge). It can be seen when Kubin convinces his brother not give the punishment for what his done. He did not feel revenge to Datuknanempat. In daily life, people in MelayuPetalangan maintained the harmony in society through honesty, patient and open hearted appears the enmity between others. So that, every difference should be hushed by forgiving each other(Effendy, 2004:367-368).

\section{Tunjuk Ajar of Honesty in NPBSU}

Honesty is the behavior that is based on the effort that makes himself as the person that always believed in the utterance, act and work for himself and for others. Based on the data analysis, it is shown that tunjuk ajar in Nyanyi Panjang Bujang Si Undang in honesty focus and responsibility practiced by the character. Character of MelayuPetalangan mentions the important of honesty, loyalty, obedient and sincerity." Siapa jujur, hidupnya mujur" (who is honest will has good luck), it means that people of MelayuPetalangan tries to implement the honesty to the children. In daily life, honest and sincere people are respected by society. Honesty is the behavior of telling the way it is, act as the way it is, responsible, and getting the rights. The things that relate with tunjuk ajar in NPBSU can be seen from tunjuk ajar of responsible, sincerity, fair, and trust(Effendy, 2004:288).

Tunjuk ajar in NPBSU shows the importance of responsibility in human life. The character of BujangsiUndang shows the way of king/ leader keeps the heirloom and if the heirloom missing, a leader must responsible for it. The request of the character to the murderer of his brother to be responsible, shows that someone need to be responsible. The request from character to the murderer of his brother is to be responsible, it shows that someone must responsible and take the risk for the things that she/he done. In order to be responsible, the children in MelayuPetalangan must be trained to understand the meaning of responsibility and shown the bad things of being irresponsible.

Besides, it is found the sincere character in NPBSU. BujangsiUndang carefully ask the existence of the heirloom. Old saying says "adat Melayu Petalangan merendah selalu" (MelayuPetalangan tradition is always modest". "modest" here means sincere, good looking, good utterance, not being coward(Effendy, 2004:201).

Moreover, tunjuk ajar NPBSU tells the main of honesty, obedient, loyalty, and sincere. It can be seen from the antagonist character named DatuknanEmpatwho is not honest about the murder of Kubin.

Because of that, he did not tell the whole story of Kubin's death to BujangsiUndang. It can be used as the understanding about tunjuk ajar about honesty. Even though it is seen from the quotation of DatuknanEmpat's dishonesty, it can be implied that we have to tell as the way things are.

In NPBSU, there is a message of tunjuk ajar about giving priority to fair and trust. Fair and trust value is also found in Nyanyi Panjang Bujang Si Undang. For people of MelayuPetalangan, fair and trust is the main key in building good luck (Effendy, 2004:95-99). Fair and trust is the reference about life, government and someone's behavior. BujangsiUndang delivers HukumnanSambilan to Datuk nan Empat to apply the fair law. The purpose is to get the fair to DatuknanEmpat about the murder of BujangsiUndang's brother named Kubin. The lines Dibaye semilan atui, Sobanyak kosik di pantai, 
Sobanyak obuk di kopalo is the form of fair and trust. These words has the fair meaning since BujangsiUndang know the impropriety about his brother's murder, but he decide to remind Datuk nan Empat about the law that need to be obeyed to the fair. Although he has his own town but he should responsible for his kingdom.

\section{Tunjuk Ajarof Intelligence in NPBSU}

Intelligence is the way people think and do something based on fact or logic in order to produce the new way or new product. Based on the data analysis, tunjuk ajar in Nyanyi Panjang Bujang Si Undang of intelligence is drawn from the character of getting knowledge and having vision. People of MelayuPetalangan is having openness character. This is the reflection of honesty, responsible and sincere. So that, this character should be inside people of MelayuPetalangan. It can be understood that intelligence is the character of active/ dynamic, logic, analysis and objective, able to solve the problem/ find the solution, creative, creating something new, consistent, positive thinking and open.

Tunjuk ajar NPBSU is also give priority to the guidance in order to make the society learn well and get knowledge related with science and technology for the life and future. High curiosity can be seen from the character, BujangsiUndang, he wants to know all information from everyone about the existence of the heirloom. He is brave to leave his hometown to get and apply the knowledge to find his heirloom. The purpose is to make the character rich of knowledge since he will face big challenge in shoreline(Effendy, 2004:108-110).

Moreover, tunjuk ajar of intelligence can be seen from the character who has vision beyond. Someone should have good insight and precise measurement. So that, it can grows the responsibility for him/ her toward the generations. Parents in MelayuPetalangan advice people to have preparation for the grandchildren. The purpose is to avoid the feeling of greedy. They will not take everything until nothing left.

Having vision beyond shown by BujangsiUndang is when he decide to go shoreline. He thought that the knowledge that he has will not grows and develop if he just stay in the town. He also thinks that it will guarantee the life of his children and grandchildren later and make the society to be prepared also(Effendy, 2004:407-408). Beside, tunjuk ajarof making use of time is also found from the character in Nyanyi Panjang Bujang Si Undang. It is shown from the way BujangsiUndang allowed to go shoreline by his mother. Her mother took seven days to discuss it with the leader of the town.

Another good behavior of people in MelayuPetalangan is thrifty and precise. They are able to find any possibility so that their life and economy can run well. By his precise character, BujangsiUndang do not easily believe that his brother passed away because of fever or stomached, he believe that his brother is murdered by someone. It makes them become careful and precise in deciding everything in life.(Effendy, 2004:302).

\section{Tunjuk Ajar of Integrity in NPBSU}

Based on data analysis, it is shown that tunjuk ajar in Nyanyi Panjang Bujang Si Undang. The focus of integrity is drawn from the character of work hard, clever and diligent, autonomous, confidence and brave. Hard work, clever and diligent becomes the responsibility for each citizen. The glory of MelayuPetalangan is determined by the citizen's sincerity in working. People of MelayuPetalangan use the work as the measurement in judging someone's personality. Someone who wants to work hard and diligent is taken as the role model, responsible and respected by the citizen. Tunjuk ajar of integrity in NPBSU is drawn from the careful, patient, discipline, tough, hard work, productive, having additional orientation, endurable, taking a risk, etc.

In tunjuk ajar of NPBSU, the hard work, diligent and patient behavior is found. BujangsiUndang without hesitant find the missing heirloom Dondang Panjang.In MelayuPetalangan tradition, this reference is already taught to the children. The nephew/niece and citizens are trained to work hard, able to face and overcome the challenge and make them become strong human (Effendy, 2004:148). 
Other way of integrity in the character can be seen from the way BujangsiUndang decide to take his brother during the searching of heirloom. Besides, it is also can be seen from the way of Kubin be brave to be alone left by his brother in the land that he do not know well. These characters show the character of MelayuPetalangan people who has high individualism and confident. It is because men from MelayuPetalangan already have enough knowledge that they learnt earlier(Effendy, 2004:173179).

Tunjuk ajar in NPBSU is also focus of the braveness. The braveness is for the right things, for the rights, for the justice, and in the way to Allah. Bujang is brave to take the blade if his brother's dead body is not treated well(Effendy, 2004:272).

\section{Tunjuk Ajar of Care in NPBSU}

Care is the behavior of human that always try to avoid the damage in environment, and develop the effort to fix the damage that already happen in environment and always want to help other people and society who needs help. Based on the data analysis, tunjuk ajar in Nyanyi Panjang Bujang Si Undang with the focus on sincere, willing to sacrifice, affection, mutual assistance and unity(Effendy, 2004:80-81).Tunjuk ajar of care in NPBSU are: obey the rules/ law, well mannered, loyal, democratic, friendly, tolerate, helpful, forgiving.

The custom of brotherhood obligateMelayuPetalangan people to do good thing sincerely. In NPBSU, it can be seen from the fact of the story that brother's death appear the deep revenge. However, with the sincere from BujangsiUndang, he has willing to let the death of his brother.

One interesting thing in NPBSU is tunjuk ajar of affection. The character shows the affection toward his brother. It can be seen when BujangsiUndang see his brother be laid to rest. In the custom and tradition of MelayuPetalangan, the effort to grow affection is stated from the child and applied in the family, neighborhood, society and nation. The children is taught about the positive way of affection and applied in daily life. So that, a good and friendly environment can be created(Effendy, 2004:227).

When BujangsiUndang decide to go shoreline, his mother is so sad and afraid of losing him. It shows the affection of parents to the child. Even though she will let her child go shoreline, Tan Gadi still wants to give advice to the child. The feeling of unity and mutual assistance is the core of MelayuPetalangan people personality. This is refers to the principal of human is unite and having affection. So that, tunjuk ajar related with unity, mutual assistance always life and inherit from one generation to others. The last thing that can be seen in tunjuk ajar NPBSU is the way of helping each other. For people in MelayuPetalangan requite is a good manner. The message from mother of BujangsiUndang is to requite someone's kindness. As the word saying "Bila hidup berbudi, sempurnalah ia mati", which means that if someone always life in helping each other and requisite someone's kindness he will get the reward in world and beyond(Effendy, 2004:187).

\section{Tunjuk Ajar of Nasionality in NPBSU}

One thing that need to be cautioned in exploring the value od education in Nyanyian Panjang Bujangsi Undang is the value of nationality. The values of nationality are described in three indicators: unity, mutual assistance and discussion and agreement. In the lif of Melayu people, they give priority of unity, mutual assistance, living with compromise in society. Parents state that the feeling of unity, mutual assistnce, living with compromise in society is the core of Melayu people. Refer to the principle of the nature of human is social creature, tunjuk ajar related with unity, mutual assistnce, living with compromise in society are inherit from one generation to the next generation. They also state that these principles will create peace in the world.

One of the foundation in Melayu tradition is discussion and agreement. Parents said that," tegak adat karena mufakat, tegak tuah karena musyawarah" (Tradition will last longer because of discussion, power will last longer because of agreement). This reference makes them respect and apply discussion and 
agreement in daily life, even for individual, family or public needs. They think that without discussion and agreement, they break the tradition and their works will not run well. They understood that through discussion and agreement the ideas and problem can be overcome and deliver. As words saying "di dalam musyawarah, buruk baiknya akan terdedah "atau "di dalam mufakat, berat ringan sama diangkat", (in discussion and agreement all the problems will be overcome).

According to tradition and custom of Melayu, if the agreement achieved, the agreement become the responsibility of society and must not neglected. All the people involved in the discussion must not avoid the responsibility. Anyone that break the agreement is seen as bad people in society. Breaking the agreement is the ashame for the family and society. As words says "bilabulatmufakat, beratringanwajibdiangkat, sebaliknya"siapa ingkar dari mufakat, tanda dirinya tidak beradat". Parents said that discussion and agreement is the media of "decision" that must be obeyed by all the members of society. The Finding was different with the research done by Nigel Phillips (1981)that found there are some moral values such as warmness, some tactics, respect to the king, justice, patient and endurance, low profile, honesty, well-mannered and responsibility.

\section{Conclusion}

Based on the findings and data analysis, it can be concluded that Nyanyi Panjang Bujang Si Undang has tunjuk ajar Melayuthat represent the ideal character of Petalangan society. Tunju kajar Melayu in Nyanyi Panjang Bujang Si Undang consist of five characters, faith and belief to God, honesty, intelligence, integrity, care and nasionality. Tunjuk ajar relates with faith and belief to God can be seen from the obedient to parents, obedient to leader, trusteeship, good prejudice, shy, forgiving, and helpful. Tunjuk ajar relates with honesty in NPBSU can be seen from responsibility and honesty. Third, the things relate with intelligence can be seen from the priority of getting knowledge, having vision, economical and precise. Fourth, tunjuk ajar in Nyanyi Panjang Bujang Si Undang with the focus character of integrity is drawn from the character of hard work, diligent, sincere, confident and brave. Fifth, tunjuk ajar inNyanyi Panjang Bujang Si Undang with the focus on care is drawn from the character of sincere, willing to sacrifice and affectionate.

\section{References}

Danandjaja, James. (2007). Folklor Indonesia, IlmuGosip, Dongengdan lain-lain. Jakarta: Grafiti Press.

Djamaris, Edwar. (1990).Menggali Khazanah Sastra Melayu Klasik. Jakarta: Balai Pustaka

Djamaris, Edwar, dkk. (1994).Sastra Daerah di Sumatera: Analisis Tema, Amanat dan Nilai Budaya. Jakarta: Balai Pustaka

Effendy, Tenas dkk. (Pnys). (1988). Nyanyi Panjang Orang Talang: Bujang si Undang. Pekanbaru: Pemerintah Daerah Tingkat I Provinsi Riau.

Effendy, Tenasdkk.(2004). Tunjuk Ajar Orang Melayu (Butir-butir Budaya Melayu Riau). Yogyakarta: Balai Kajian danPengembangan Budaya Melayu.

Hasanuddin WS.(2015).TransformasidanProduksiSosialTeksMelaluiTanggpandanPenciptaanKaryaSastra: Kajian Intertekstualiatas Tek scerita Anggun Nan Tongga Magek Jabang. Bandung:Angkasa

Hasanuddin WS.(2015). Sastra Anak: KajianTema, Amanat dan Teknik Penyampaian Cerita Anak Terbitan Surat Kabar. Bandung: Angkasa.

Nigel, Phillips. (1981). Si Jobang: Sung Narrative Puetry of West Sumatra. London: London University. Shomary, Sudirman. (2004). NyanyiPanjang Orang Petalangan.Pekanbaru: UIR Press.

Sweeney, Amin. (1988). Orality and Oracy," Old English Colloquium, Berkeley.

Yoonhee Kang. (2005). Ancestor Words. US: Yale University. 